\title{
Seed germination behaviour of the narrow endemic Daphne arbuscula (Thymelaeaceae) compared to the more widespread Daphne cneorum
}

\author{
Alice Di Sacco • Zuzana Gajdošová • Marek Slovák (D) I Ingrid Turisová • Peter Turis • \\ Jaromír Kučera $\cdot$ Jonas $\mathbf{V}$ Müller
}

Received: 8 October 2020 /Revised: 22 January 2021 / Accepted: 11 March 2021 / Published online: 17 June 2021

(C) The Author(s) 2021

\begin{abstract}
Diminished reproduction success in species with narrow distribution ranges might be one of the factors responsible for their limited dispersal and colonization abilities. We investigated here various aspects of the seed biology of the West Carpathian endemic Daphne arbuscula (Thymelaeaceae) and compared it with its more widespread relative $D$. cneorum. In both species, we investigated (i) differences in seed viability and germination ability; (ii) differences between the two observed fruit morphotype groups, and (iii) the effect of cold stratification in breaking seed dormancy and
\end{abstract}

A. Di Sacco · J. V. Müller

Royal Botanic Gardens, Kew, Millennium Seed Bank, Wakehurst Place, Ardingly, West Sussex RH17 6TN, UK

Z. Gajdošová · M. Slovák · J. Kučera

Plant Sciences and Biodiversity Centre, Institute of Botany,

Slovak Academy of Sciences, Dúbravská cesta 9, 845

23 Bratislava, Slovakia

M. Slovák $(\bowtie)$

Department of Botany, Charles University, Benátská 2, CZ-128

01 Praha, Czechia

e-mail: marek.slovak@savba.sk

I. Turisová

Faculty of Natural Sciences, Matej Bel University in Banská

Bystrica, Tajovského 40, 97401 Banská Bystrica, Slovakia

P. Turis

Low Tatras National Park Administration, State Nature Conservancy of the Slovak Republic, Partizánska cesta 69, 974

00 Banská Bystrica, Slovakia enhance germination in stored seeds. To determine seed viability, a tetrazolium test and an imbibed cut test were performed. Several seed germination tests with gibberellic acid and with a sequence of cold and warm stratification, using different temperatures and durations, were carried out. We uncovered that (i) D. arbuscula seeds show significantly lower viability than $D$. cneorum seeds, but this difference is due to the smaller-fruit morphotype; (ii) seed quality and viability of the big-fruit morphotype are significantly greater than the smaller-fruit morphotype in both species, although the seed viability of the latter is not null and the dormancy level seems to differ between them; (iii) a warm stratification at $15^{\circ} \mathrm{C}$ for 13 weeks, followed by cold stratification at either 0 or $5^{\circ} \mathrm{C}$ for 28 weeks, followed by 4 weeks at $15^{\circ} \mathrm{C}$, break physiological dormancy and allow the majority of seeds of D. arbuscula (63\%) to germinate. We recommend including both fruit morphotypes when collecting seed of Daphne for ex situ conservation and reintroduction initiatives, to maintain the original genetic diversity of the species.

Keywords Daphne arbuscula · Daphne cneorum · Fruit polymorphism · Seed dormancy $\cdot$ Seed germination .

Seed viability

\section{Introduction}

Members of the genus Daphne L. (Thymelaeaceae Juss.) are widely known not only as valuable ornamental shrubs in horticulture but also as a textbook example of 
a genus with extensive diversification of endemic entities (Tutin 1968; Halda 2001; Yinzheng et al. 2007). Indeed, a large number of Daphne species are endemics and restricted to only small areas of distribution. For instance, out of thirty European species, more than twenty are endemics of single mountain ranges or islands (Tutin 1968; Halda 2001; Pedrol 2011). The genus encompasses up to 95 deciduous or evergreen shrubs native to temperate and subtropical parts of Europe, Asia and North Africa (Tutin 1968; Halda 2001). Most of the species flower in late winter or early spring with colourful, scented flowers formed by petaloid sepals forming a flower cup (hypanthium). They are reported to be mostly self-incompatible and entomophilous. Fruits are dry or fleshy, oneseeded drupes; zoochory is the primary dispersal mechanism (Halda 2001).

In contrast to its horticultural and scientific attractiveness, the genus is, in general, understudied with regard to its reproduction strategies, seed biology and germination ability (but see e.g. Zhang and Smagula 2000; Alonso and Herrera 2001; White 2006; Filipovič 2011; Baskin and Baskin 2014; Fang et al. 2016). The viability and germination ability of seeds of the few Daphne species studied were shown to be considerably low, which points towards a problem with their generative reproduction (e.g. Erdelská and Turis 1995, 1996; Šedivá and Žlebčík 2010; Ari et al. 2014). One of the crucial factors considered responsible for the decreased germination ability in Daphne is physiological dormancy (hereafter abbreviated as PD; White 2006; Ari et al. 2014). However, PD might be overcome, for instance, by cold stratification treatment (Zhang and Smagula 2000; Fang et al. 2016).

In this study, we focused on Daphne arbuscula Celak., one of the well-known narrow endemics in the genus. It only occurs in the Muránska planina mountains in the Western Carpathians in Slovakia (Krippel and Goliašová 1988). It is an evergreen dwarf shrub, up to $25 \mathrm{~cm}$ tall (Krippel and Goliašová 1988; Turis 1994), with shiny revolute leaves and pink to purple-violet, sweetly scented flowers. It occupies sunny rocky slopes and rock terraces on limestone bedrock between 590 and 1,330 m a.s.l. (Erdelská and Turis 1996; Kochjarová et al. 1999). The second species of interest, D. cneorum L., is morphologically very similar to $D$. arbuscula but differs predominantly by its finer leaves and their position on the stem. It is widespread across Europe with an area of distribution ranging from Spain to Russia (Tutin
1968; Halda 2001). Both species are diploid with $2 x=$ $2 n=18$ and are reported to be allogamous and entomophilous (Erdelská 1998; Marhold et al. 2007). Their fruits are one-seeded drupes. Interestingly, morphological fruit polymorphism has been observed in both species [D. arbuscula (Turis, unpublished data) and D. cneorum (Gajdošová 2018)]. Based on the colour and thickness of the mesocarp, fruits of both species can be assigned to two, essentially discrete, categories. The first fruit morphotype includes fruits that are bigger and have a large, fleshy mesocarp. They have a yellow to yellowish-brown colour (referred to below as the 'bigfruit morphotype'; Figs. 1a,b and 2a,b). The second fruit morphotype (referred to below as the 'small-fruit morphotype') consists of smaller and harder fruits, characterized by a reduced mesocarp, which is at first sight significantly thinner than the mesocarp of the 'big-fruit morphotype'. The fruit colour of the 'small-fruit morphotype' ranges between green reddish and reddish-brown in D. arbuscula, but is greenish in D. cneorum (Figs. 1d,e and 2d,e). In both species, the seeds of both fruit morphotypes do not show any noticeable morphological differences (Figs. 1c,f and 2c,f). Importantly, however, the fruits are dispersed at the same time (Gajdošová 2018; authors' own observations). It has been left unclear whether these two fruit morphotype groups represent actual fruit polymorphism or only a specific stage during the fruit ripening process. Furthermore, the seeds of both species are suspected to show PD, similar to other Daphne species (Erdelská and Turis 1995, 1996; White 2006). Several studies on various aspects of the biology, chorology and ecology including seed embryology of $D$. arbuscula have been published to date (Erdelská et al. 1989; Murín 1990; Erdelská and Turis 1995, 1996; Turis and Smetana 1997; Erdelská 1998, 1999; Kochjarová et al. 1999). Some of these studies even provided first insights into the reproductive strategies and mechanisms in D. arbuscula, highlighting decreased fruit formation, seed viability, germination ability, and a role of the fruit mesocarp as a factor inducing and prolonging the physiological dormancy of seeds (Erdelská and Turis 1995; Filipovič 2011). Previous experiments pointed towards a very low germination ability of $D$. arbuscula (Erdelská and Turis 1995, 1996) and D. cneorum (Šedivá and Žlebčík 2010). Furthermore, Filipovič (2011) examined the influence of various factors stimulating and controlling seed germination in D. arbuscula and showed that certain stimulators increase seed 

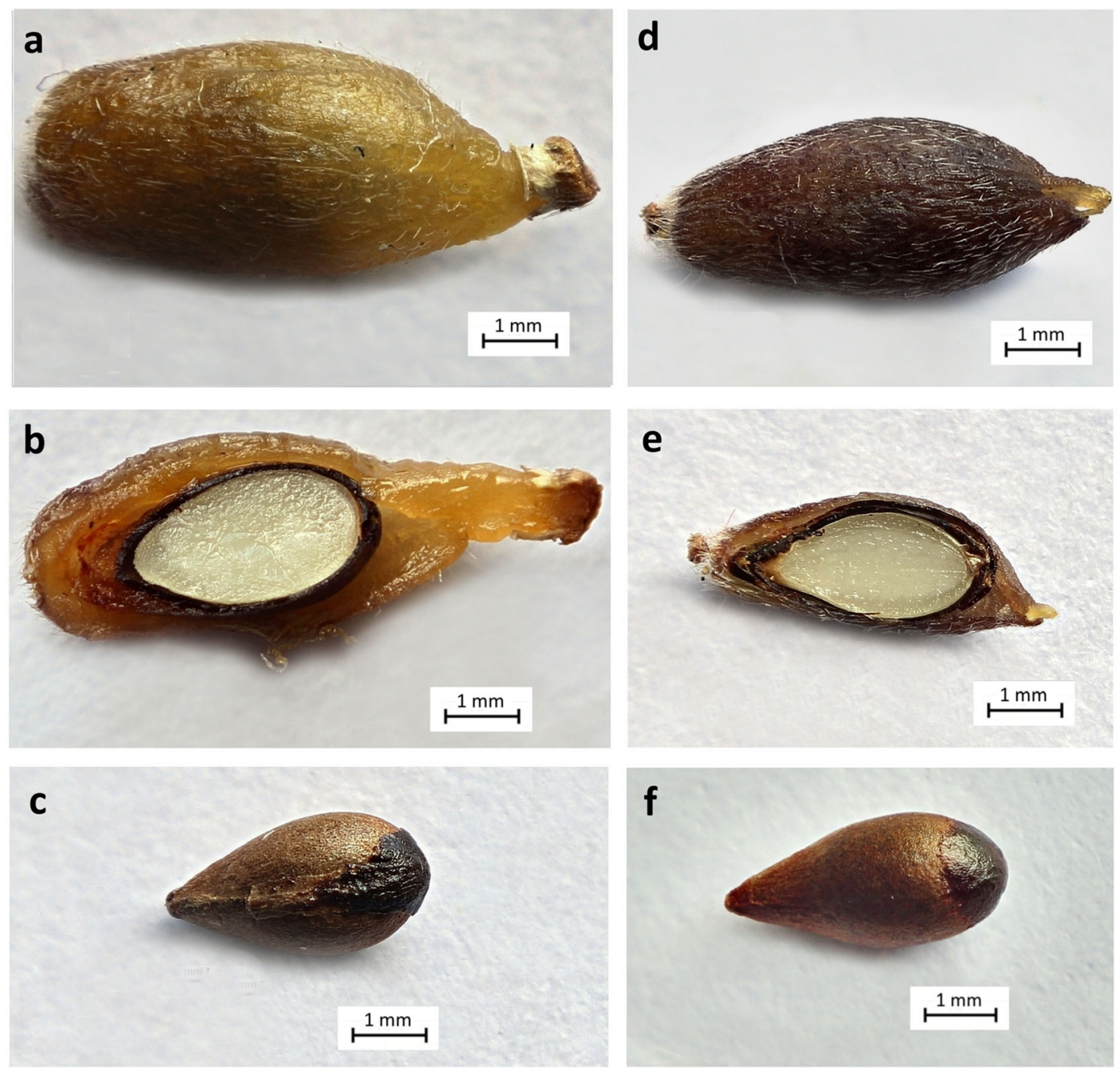

Fig. 1 Fruits and seeds of Daphne arbuscula; big-fruit morphotype: a - fruit, b - fruit cross-section, c - seed; small-fruit morphotype: $\mathbf{d}$ fruit, $\mathbf{e}$ - fruit cross-section, $\mathbf{f}-$ seed

germination. However, this study did not include crucial environmental factors such as the temperature which controls seed germination and physiological dormancy. Likewise, none of these studies addressed the morphological fruit polymorphism and any potential differences in seed viability between them.

For these reasons, based on previously obtained knowledge on seed production, viability and dormancy in D. arbuscula predominantly in situ (Erdelská and Turis 1995, 1996), we examined the ex situ seed germination of $D$. arbuscula after storage, also to give recommendations to seed conservation practitioners on the best protocol to germinate this threatened species, and therefore favouring its reinforcement in the wild. In particular, we focussed on the differences in viability and germination abilities between the observed fruit morphotypes, to inform the best seed collecting procedures for this species. We studied the influence of temperature regime and gibberellic acid to break potential physiological seed dormancy. We tested the following specific hypotheses:

1. The overall seed viability and germination ability of the endemic $D$. arbuscula is critically low compared to the closely related but much more widespread species D. cneorum.

2. Seeds of the two fruit morphotype groups of D. arbuscula differ in their levels of viability. Specifically, based on previous observations (Turis, personal communication), we expected a 

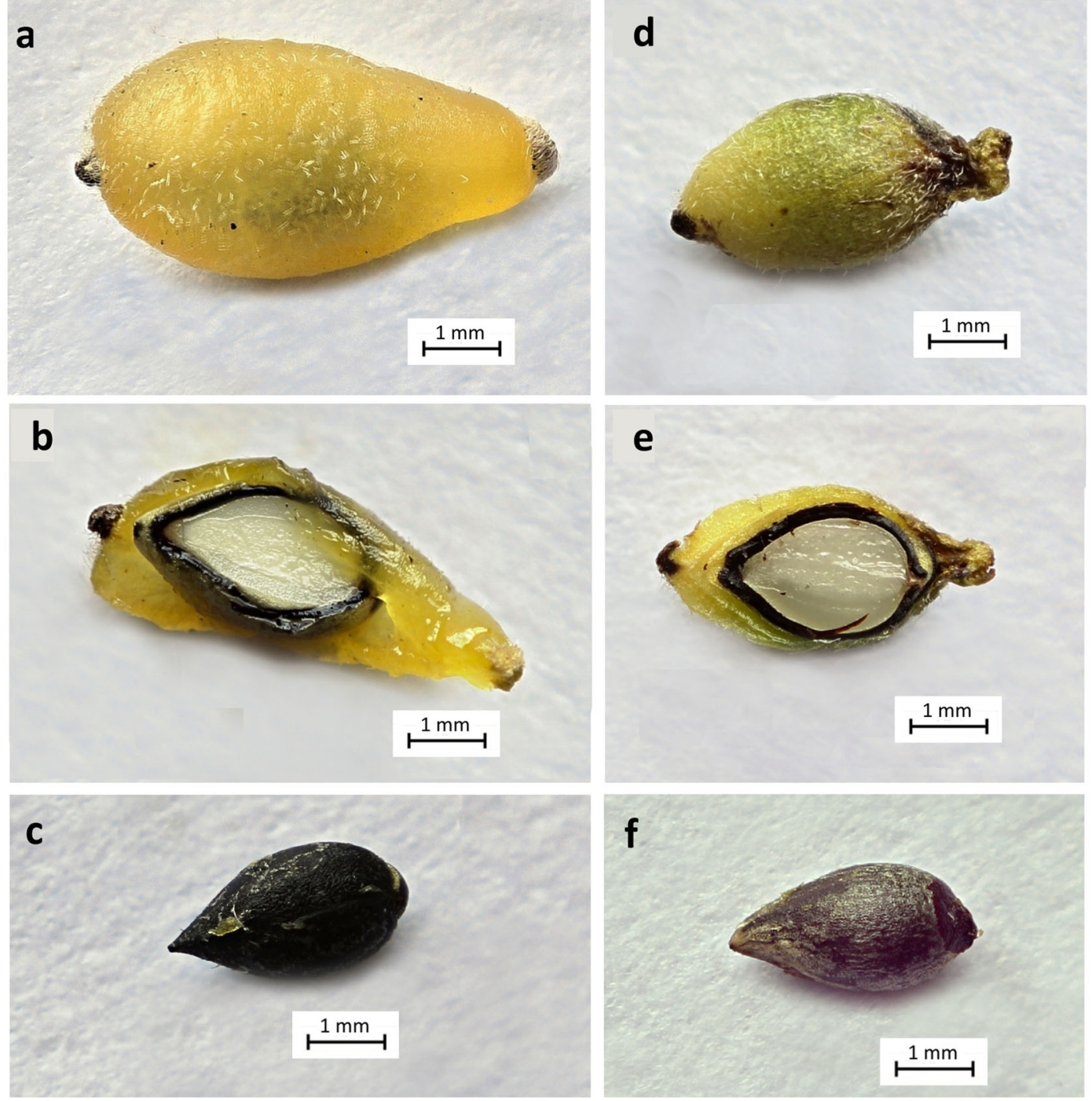

Fig. 2 Fruits and seeds of Daphne cneorum; big-fruit morphotype: a - fruit, b - fruit cross-section, c - seed; small-fruit morphotype: d fruit, $\mathbf{e}$ - fruit cross-section, $\mathbf{f}-$ seed

significantly lower or even no viability in the 'small-fruit' morphotype.

3. Long-term exposure of seeds to cold stratification breaks the dormancy and increases seed germination in D. arbuscula.

\section{Material and methods}

Ripe seeds of $D$. arbuscula (four populations) and D. cneorum (one population) were collected in June and July 2018 from natural populations in the Western
Carpathians (Slovakia) at the time of their natural dispersal (see Table S1).

Because the populations of $D$. arbuscula were greatly restricted and the majority of individuals difficult to reach or not accessible at all (e.g. situated on vertical cliffs), and the collection was limited to the $20 \%$ of available seeds in order not to compromise the survival of the populations (Pedrini et al. 2020), the overall number of seeds collected and used in this study was limited. For this reason, it was not possible to perform replicates of the experiments. Instead, statistical analysis was performed considering each seed as an individual response, as previously done successfully by Newton 
et al. (2013) and Davies et al. (2016). For all five populations, seeds from the two fruit morphotypes were collected and kept separately. Seeds were cleaned and removed from fruits shortly after collection to avoid any unintended influence of the mesocarp potentially blocking seed germination (Filipovič 2011). Afterwards, seeds were dried at $15 \%$ equilibrium relative humidity at $15^{\circ} \mathrm{C}$, then shipped to the Millennium Seed Bank (MSB) for testing, which started in January 2019.

\section{Viability tests}

Prior to germination tests, we studied the overall viability of $D$. arbuscula seeds from both fruit morphotypes. To verify the potential difference in seed viability between seeds from the small-fruit morphotype vs the bigfruit morphotype, two different viability tests (tetrazolium test and imbibed cut test) were performed (Davies et al. 2015a). To avoid possible population effects, seeds of $D$. arbuscula from both morphotypes collected in the four populations as shown in Table S1 were mixed prior to the tests. Because of variable seed availability, the number of seeds per collection was not equal, but within each population we used the same number of seeds for each morphotype so as to ensure the same contribution of each population to the morphotype groups. Both tests were also performed on seeds of the closely related species D. cneorum from the locality Baba (see Table S1).

Fifty seeds of each morphotype group of each species were used for the tetrazolium (TZ) test, following the MSB standard procedure $\left(24 \mathrm{~h}\right.$ rehydration over water at $20^{\circ} \mathrm{C}$, $48 \mathrm{~h}$ on $1 \%$ agar at $20^{\circ} \mathrm{C}$, seed excision at cotyledons' end, followed by $48 \mathrm{~h}$ in $1 \% \mathrm{TZ}$ solution at $30^{\circ} \mathrm{C}$ in the darkness). The seeds were scored under a stereomicroscope and different colour categories were noted. As no literature is available to guide the interpretation of the TZ results for these species, two possible viability interpretations were recorded, one where only the fully red seeds were counted as viable (referred to below as 'Low TZ'), and another one where both, the fully red and the red with small patches of pink colour were considered viable (referred to below as 'High TZ'). White, pink or mouldy seeds were always considered not viable. The number of empty seeds was recorded, too.

At the same time, fifty seeds of each morphotype group of each species were used for the imbibed cut test, which was performed by dissecting the seeds under a stereomicroscope after 4 weeks of imbibition on $1 \%$ agar at $15^{\circ} \mathrm{C}$.
The following categories were identified: viable (fresh, healthy tissues), not viable (mouldy, necrotic, soft tissues) and empty seeds. This test was used to validate the $\mathrm{TZ}$ interpretations described above, so only the most reliable interpretation was used in the study.

\section{Daphne arbuscula germination tests}

Because of the limited number of available seeds in this study, we were able to test only few germination and stratification temperatures. Only seeds from the big-fruit morphotype of $D$. arbuscula of the population in Šiance were used for the germination tests. To choose the most likely successful ones, we used available actual climatic data at the sites of natural occurrence as a proxy. Actual climatic data of Šiance for long-term average monthly temperatures measured between 1994 and 2019 were extracted from SolarGIS (Bratislava, Slovakia) and used, with reasonable approximation, as germination and stratification temperatures (Table S2).

Four germination tests with fifty seeds each were set up (Table 1). Seeds were exposed to initial warm stratification ( 4 weeks), followed by a period of cold stratification at 0 or $5^{\circ} \mathrm{C}$ ( 8 weeks), followed by the spring temperature regime (10 weeks), when one would expect the seeds to germinate. For both, warm stratification and spring temperatures, constant $\left(15^{\circ} \mathrm{C}\right)$ and alternating temperature $\left(25 / 5^{\circ} \mathrm{C}\right)$ regimes were tested. At each stage, we used a photoperiod of $12 \mathrm{~h}$. The lengths of the different steps were shorter than the natural seasons to make the tests doable in the laboratory. However, as suggested for move-along experiments (Kildisheva et al. 2020), an additional two germination tests were set up using the full length of seasons (13 weeks warm stratification and 28 weeks for cold stratification). For these tests, only a constant temperature $\left(15^{\circ} \mathrm{C}\right)$ for warm stratification and the spring temperature regime was applied whereas both $0^{\circ} \mathrm{C}$ and $5^{\circ} \mathrm{C}$ were tested for cold stratification.

Germination tests were performed using Petri dishes with a $1 \%$ agar substrate. Germinated seeds were counted and discarded weekly, and tests were abandoned after a minimum of 4 weeks with no further germination event. Final cut tests were done by dissecting the nongerminated seeds under a stereomicroscope and these seeds categorized as either fresh and healthy (f), mouldy and dead, empty (e), or infested (i). Following standard protocols (Davies et al. 2015a), germination $(G)$ and estimated viability $(\mathrm{V})$ percentages were calculated as: $G=g \times 100 /($ s-e-i) and $V=(g+f) \times 100 /($ s-e-i), where $g$ 
Table 1 Constant and alternating temperatures used for warm stratification, cold stratification and spring temperature treatments (with lengths of exposure) in the six seed germination tests of
D. arbuscula and resulting final germination, viability percentage, mean germination time (MGT) and germination synchrony (SYN).

\begin{tabular}{|c|c|c|c|c|c|c|}
\hline Warm stratification & Cold stratification & Spring temperatures & Germination [\%] & Viability [\%] & MGT [days] & SYN \\
\hline $\begin{array}{l}15^{\circ} \mathrm{C} \\
\text { (4 weeks) }\end{array}$ & $\begin{array}{l}0^{\circ} \mathrm{C} \\
\text { (8 weeks) }\end{array}$ & $\begin{array}{l}15^{\circ} \mathrm{C} \\
(10 \text { weeks) }\end{array}$ & 51 & 91 & 99.9 & 0.6 \\
\hline $\begin{array}{l}15^{\circ} \mathrm{C} \\
(4 \text { weeks) }\end{array}$ & $\begin{array}{l}5^{\circ} \mathrm{C} \\
(8 \text { weeks })\end{array}$ & $\begin{array}{l}15^{\circ} \mathrm{C} \\
(10 \text { weeks })\end{array}$ & 42 & 78 & 100 & 0.34 \\
\hline $\begin{array}{l}25 / 5^{\circ} \mathrm{C} \\
(4 \text { weeks) }\end{array}$ & $\begin{array}{l}0^{\circ} \mathrm{C} \\
\text { (8 weeks) }\end{array}$ & $\begin{array}{l}25 / 5^{\circ} \mathrm{C} \\
(10 \text { weeks) }\end{array}$ & 11 & 15 & 92.6 & 0.3 \\
\hline $\begin{array}{l}25 / 5^{\circ} \mathrm{C} \\
\text { (4 weeks) }\end{array}$ & $\begin{array}{l}5^{\circ} \mathrm{C} \\
(8 \text { weeks })\end{array}$ & $\begin{array}{l}25 / 5^{\circ} \mathrm{C} \\
(10 \text { weeks) }\end{array}$ & 16 & 24 & 84 & 0.29 \\
\hline $\begin{array}{l}15^{\circ} \mathrm{C} \\
(13 \text { weeks })\end{array}$ & $\begin{array}{l}0^{\circ} \mathrm{C} \\
(28 \text { weeks })\end{array}$ & $\begin{array}{l}15^{\circ} \mathrm{C} \\
(4 \text { weeks) }\end{array}$ & 63 & 63 & 297.7 & 0.44 \\
\hline $\begin{array}{l}15^{\circ} \mathrm{C} \\
(13 \text { weeks })\end{array}$ & $\begin{array}{l}5^{\circ} \mathrm{C} \\
(28 \text { weeks })\end{array}$ & $\begin{array}{l}15^{\circ} \mathrm{C} \\
\text { (4 weeks) }\end{array}$ & 57 & 57 & 271.3 & 0.5 \\
\hline
\end{tabular}

$=$ number of germinated seeds and $s=$ number of sown seeds. The viability calculated here does not indicate the original viability of the seed collections, as the effect of long germination tests might affect seed viability. For this reason, the intention in this case was to show the effect of certain germination conditions on seed viability.

Mean germination time (MGT), expressed in days, was calculated for each test as:

MGT $=\sum(n, t) / \sum n$, where $t$ is time from the beginning of the germination test in terms of days, and $n$ is the number of newly germinated seeds at time $t$ (Ranal et al. 2009; Lozano-Isla et al. 2019). Germination synchrony (SYN), expressed as a value between 0 and 1 , was calculated as: $\mathrm{SYN}=\left(\sum C n_{1,2}\right) / N$, where $C n_{1,2}=\left[n_{\mathrm{i}}\left(n_{\mathrm{i}}-1\right)\right] / 2$ and $N=\left[\sum n_{\mathrm{i}}\left(\sum n_{\mathrm{i}}-1\right)\right] / 2$, and $n_{\mathrm{i}}$ is the number of seeds germinated in the $i^{\text {th }}$ time. When synchrony is equal to 1 , seed germination occurs at the same time whereas synchrony near 0 denotes that at least two seeds complete the germination process at different times (Ranal et al. 2009; Lozano-Isla et al. 2019).

\section{GA3 tests}

To assess the difference in dormancy level between the two morphotypes of both species $D$. arbuscula and $D$. cneorum, as well as between the species, a further germination test with gibberellic acid (GA3) was performed. Prior to the test, seeds of $D$. arbuscula from four populations were mixed as described above. Fifty seeds of each fruit morphotype of each species were sown on $1 \%$ agar with dissolved GA3 at a concentration of $250 \mathrm{mg} / \mathrm{l}$, as described in Davies et al. (2015a). Plates were incubated at $15^{\circ} \mathrm{C}$ and under a 12 -h photoperiod. Germinated seeds were counted and discarded weekly, and tests were run for 13 weeks. Final cut tests were done by dissecting the non-germinated seeds under a stereomicroscope. Germination percentages were calculated as described above.

Statistical analysis

To assess the best TZ interpretation, the two results Low TZ and High TZ were compared with the imbibed cut test using the Pearson's chi-square test, or the Fisher's exact test where any of the expected values were $<5$. The same statistical tests were used to compare the viability of the two fruit morphotypes for each species and to compare the viability between the two species.

To assess the effect of each variable tested with the germination tests (germination temperature, stratification temperature and stratification length), a logistic regression with categorical variables was performed. Both, germination and viability estimated through final cut tests were analysed.

To calculate MGT and SYN, the GerminaR package was used (Lozano-Isla et al. 2019).

Differences in the levels of dormancy between the fruit morphotypes and between the species were assessed through a Pearson's chi-square test, using the number of seeds germinated and non-germinated, excluding empty and infested seeds in order to assess dormancy in full seeds only, as the only ones potentially viable (Davies et al. 2015a). 
All statistical analyses were run with RStudio (RStudio Team 2019) and R (R Core Team 2020). Graphs were produced with Microsoft Office Excel.

\section{Results}

Viability tests

For both fruit morphotypes of both the species $D$. arbuscula and D. cneorum, the results of the High $\mathrm{TZ}$ test and the imbibed cut test were not significantly different (in D. cneorum $P=0.229$ and $P=0.117$ for the small- and big-fruit morphotype, respectively; in D. arbuscula $P=0.08$ and $P=1$ for the small- and big-fruit morphotype respectively, Fisher's exact test; Table 2). On the other hand, for the big-fruit morphotype of both species, the results of the Low TZ test were significantly different $(P=0.001$ and $P=$ 0.031 for $D$. arbuscula and $D$. cneorum, respectively) from the results of the imbibed cut test. Therefore, the results of the High TZ test were the most accurate for the two species, and it was used in this study to analyse the difference between the seeds of the two fruit morphotypes.

The viability of seeds contained in the big-fruit morphotype was very high for both species $(94 \%$ in D. arbuscula, $100 \%$ in D. cneorum), and the smallerfruit morphotypes contained fewer viable seeds ( $58 \%$ in D. arbuscula, $86 \%$ in D. cneorum).

As is apparent already from the percentages of seed viability, there was a statistically highly significant difference between the two fruit morphotypes in terms of the quality (expressed as the proportion of full vs empty seeds) and viability of the seeds of both species, D. $\operatorname{arbuscula}(P<0.001$, Fisher's exact test $)$ and D. cneorum ( $P=0.006$, Fisher's exact test).
Seed viability differed between the two species, being greater in $D$. cneorum (Table 2). This difference was significant if all seeds were taken into account $(P=$ 0.007 , Fisher's exact test), but that was due to the lower viability of the seeds of the small-fruit morphotype in D. arbuscula $(P=0.011$, Fisher's exact test $)$, as no significant difference $(P=0.242$, Fisher's exact test) was found between the seeds of the big-fruit morphotype.

\section{Daphne arbuscula germination tests}

The highest seed germination (63\%) of D. arbuscula, of seeds collected from the big-fruit morphotype, was achieved after 13 weeks of warm stratification at $15^{\circ} \mathrm{C}$ incubation, followed by 28 weeks of cold stratification at $0^{\circ} \mathrm{C}$, followed by $15^{\circ} \mathrm{C}$ incubation (Table 1 ).

Germination at a constant temperature of $15^{\circ} \mathrm{C}$ (42 to $63 \%$ ) was notably greater than at alternating temperatures of $25 / 5^{\circ} \mathrm{C}$ (11 to $16 \%$ ), confirmed by the logistic regression $(P<0.001)$. Similarly, seed viability estimated by a cut test after seeds were exposed to constant temperature (57 to 91\%) was significantly greater than when seeds were exposed to alternating temperatures (15 to $24 \%$ ), also confirmed by logistic regression $(P<0.001)$.

In the germination tests at constant temperatures, the lower temperature used for cold stratification, $0^{\circ} \mathrm{C}$, achieved greater germination success but the difference was not significant $(P=0.586)$. This result was confirmed even when the logistic regression was applied to the tests at constant temperatures only.

Finally, the duration of the stratification treatments had a slight impact on the final germination results, with the longer time (13 weeks for warm and 28 weeks for cold stratification) resulting in higher germination percentages; however, this difference was not confirmed by logistic regression $(P=0.075)$.

Table 2 Numbers of viable, not viable and empty seeds in TZ viability and imbibed cut viability (ICT) tests for each fruit morphotype in both species. BFM - the big fruit morphotype, SFM - the small fruit morphotype

\begin{tabular}{|c|c|c|c|c|c|c|c|c|c|c|c|c|}
\hline & \multicolumn{3}{|c|}{$\begin{array}{l}\text { D. arbuscula } \\
\text { SFM }\end{array}$} & \multicolumn{3}{|c|}{$\begin{array}{l}\text { D. arbuscula } \\
\text { BFM }\end{array}$} & \multicolumn{3}{|c|}{$\begin{array}{l}\text { D. cneorum } \\
\text { SFM }\end{array}$} & \multicolumn{3}{|c|}{$\begin{array}{l}\text { D. cneorum } \\
\text { BFM }\end{array}$} \\
\hline & High TZ & Low TZ & $\mathrm{ICT}$ & High TZ & Low TZ & ICT & High TZ & Low TZ & $\mathrm{ICT}$ & High TZ & Low TZ & ICT \\
\hline Viable & 29 & 24 & 18 & 47 & 32 & 46 & 43 & 33 & 37 & 50 & 37 & 46 \\
\hline Not viable & 15 & 20 & 21 & 3 & 18 & 4 & 5 & 15 & 11 & 0 & 13 & 4 \\
\hline Empty & 6 & 6 & 11 & 0 & 0 & 0 & 3 & 3 & 2 & 0 & 0 & 0 \\
\hline
\end{tabular}


MGT varied from 84 to 100 days in the short tests and from 271 to 298 days in the long tests (Table 1). Germination was concentrated immediately after the cold stratification, with just a few seeds germinating during the warm stratification. Exceptionally, when the cold stratification at $5^{\circ} \mathrm{C}$ lasted for the full length of the winter, seeds started to germinate after 24 weeks under the winter temperature regime (Fig. 3).

Germination synchrony (SYN) varied from 0.29 to 0.6 (Table 1). These values, distant from 0 , were due to the germination being spread over two periods (warm stratification and the spring temperature regime), and in one case to the cold stratification period.

\section{GA3 tests}

When comparing seed germination with GA3 between the fruit morphotypes, the two species behaved in opposite ways (Table 3). In D. cneorum, seeds of the small-fruit morphotype (39\%) achieved significantly greater germination than seeds from the big-fruit morphotype $(8 \% ; P<$ $0.001)$. On the other hand, in D. arbuscula more seeds of the big-fruit morphotype (46\%) germinated compared to the small-fruit morphotype (30\%), but the difference was not significant $(P=0.12)$.
Table 3 Germination percentages after 13 weeks of incubation at $15^{\circ} \mathrm{C}$ under a 12 -h photoperiod on $1 \%$ agar with dissolved GA3 at a concentration of $250 \mathrm{mg} / \mathrm{l}$. Statistically significant differences between fruit morphotypes and species are shown $(* P<0.05 ; * * P$ $<0.01 ; * * * P<0.001)$.

\begin{tabular}{llll}
\hline & $\begin{array}{l}\text { Daphne } \\
\text { arbuscula }\end{array}$ & D. cneorum & $\begin{array}{l}\chi^{2} \\
\text { between } \\
\text { species }\end{array}$ \\
\hline Big-fruit morphotype & $46 \%$ & $8 \%$ & $* * *$ \\
$\begin{array}{l}\text { Small-fruit morphotype } \\
\chi^{2} \text { between fruit }\end{array}$ & $30 \%$ & $39 \%$ & - \\
$\quad-$ & $* * *$ & - \\
\hline
\end{tabular}

Overall, comparison of the two species, revealed that seeds of $D$. arbuscula germinated significantly better than those of $D$. cneorum ( $P=0.019)$, but only due to the highly significant difference between the big-fruit morphotypes of the two species $(P<0.001)$.

\section{Discussion}

Relationship between fruit polymorphism and seed viability in Daphne arbuscula and D. cneorum

\section{Cumulative germination}

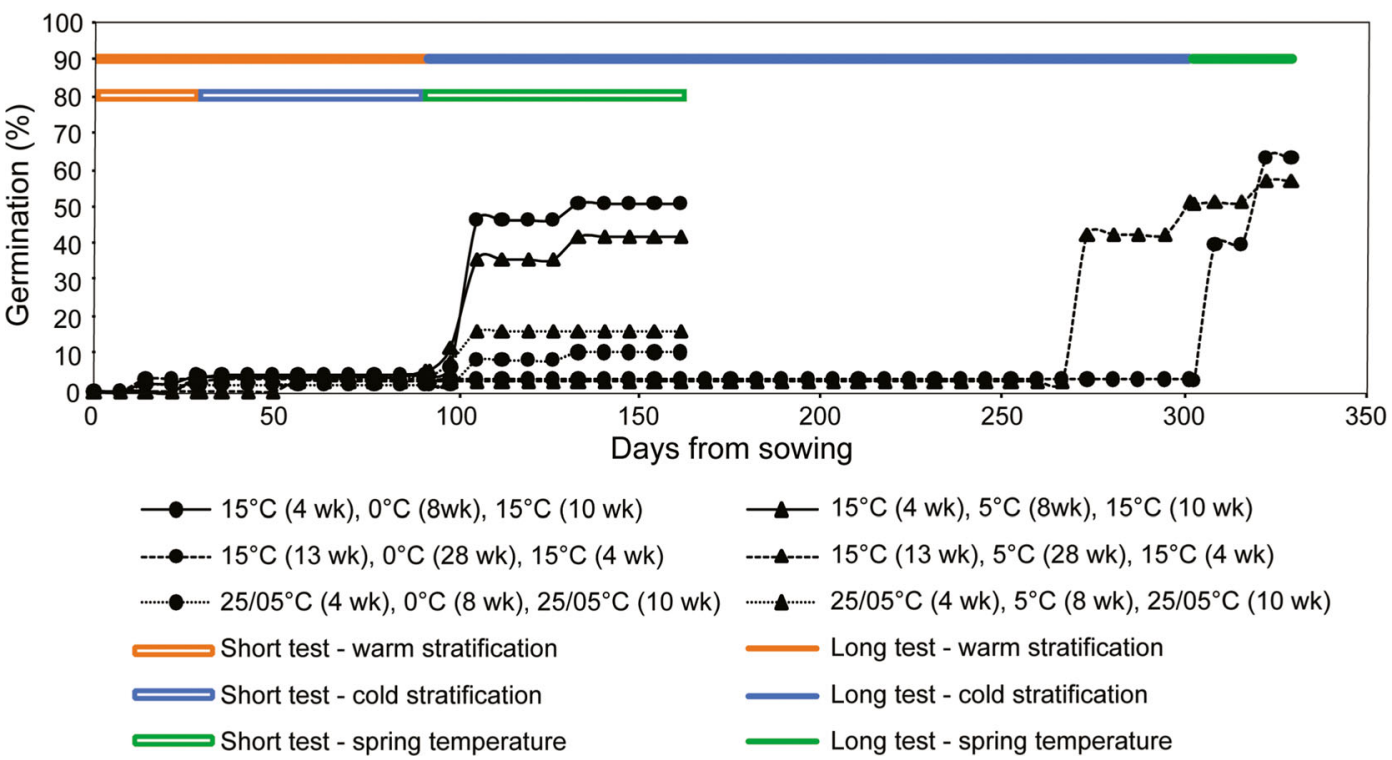

Fig. 3 Cumulative germination percentages for the six seed germination tests of Daphne arbuscula for each day; stratification lengths are shown, too 
Our study shows that $D$. arbuscula has statistically lower seed viability compared to the more widespread D. cneorum. This finding supports the hypothesis about decreased seed viability in this steno-endemic species which, in consequence, might negatively affect its overall generative reproduction. Indeed, the proved decrease in seed viability in D. arbuscula might represent one of the factors previously hypothesized to be responsible for the restricted distribution and rarity of the species (see Erdelská and Turis 1995, 1996).

Significant differences between the viability of seeds of big- and small-fruit morphotypes in both species were, however, apparent at first sight (see the subsection Results - Viability tests). The seeds extracted from the big-fruit morphotype reached high levels of viability, indicating no substantial problems with embryo development and the formation of viable seeds. By contrast, seeds from the-small-fruit morphotype showed significantly lower viability. Although the viability of seeds from the small-fruit morphotype exceeded in both species a 50\% threshold, their formation and dispersal are likely to be suboptimal for the generative reproduction of these species.

The precise reason for the decreased seed viability of the small-fruit morphotype is left unresolved and calls for further investigation. Indeed, the significantly lower viability of seeds from the small-fruit morphotype could point towards an earlier ontogenetic stage of the fruits. However, even if both fruit morphotypes represent only different ontogenetic stages of the fruit ripening process, we can only speculate which specific intrinsic or extrinsic factors or their combination are responsible for the early dispersal of at least partially unripe fruits. By contrast, the fact that both morphotypes are dispersed at the same time could rather support the existence of actual fruit polymorphism. If this is the case, one would have to ask about its origin and functionality. The thickness and structure of the mesocarp have an impact on water absorption, gas exchange or protection against pathogens and on the germination ability of seeds (Mohamed-Yasseen et al. 1994; Imbert 2002). In both species, the formation of fruits with large and thick mesocarps might be a strategy to protect seeds against desiccation at their localities during the relatively dry and hot summer period. The formation of a fleshy mesocarp, restricted to only some fruits, might also be associated with a somehow restricted availability of certain resources, specifically water. Indeed, a similar type of fruit dimorphism was detected in Thymelaea velutina (Pourr. ex Cambess.) Endl. (Thymelaeaceae). This species, which is endemic to the Balearic Islands, is known for its fruit heterocarpy. It forms two types of drupes: a 'dry' form with a thin mesocarp and a yellow form with thick, fleshy fruits (Tebar and Llorens 1993; de la Bandera and Travaset 2006). The morphoanatomical difference of the mesocarp might be a response to different ecological conditions, especially water availability and/or temperature. A third possible explanation is that fleshy mesocarps might serve to attract insects or small vertebrates and support seed dispersal via endozoochory (e.g. Halda 2001; de la Bandera and Travaset 2006). The presence of fleshy tissues in fruits might not only be a mechanism protecting seeds or attracting dispersal vectors, but it can also have a direct function in controlling the seed germination process. Indeed, fleshy tissues that contain inhibitors which hamper seed germination have repeatedly been evidenced in the genus Daphne (Mathew 1989; Zhang and Smagula 2000; Filipovič 2011). It was found that the germination ability of uncleaned seeds of $D$. arbuscula including also mesocarp tissue decreased sharply to $24 \%$ whereas the germination of cleaned seeds without mesocarp tissue reached $66 \%$ (Filipovič 2011). Furthermore, Zhang and Smagula (2000) reported for D. mezereum L. that a colour variation of its fleshy fruits (green, red and brown) was associated with the maturation stage and germination ability. All colour-associated fruit morphotypes encompassed mature and viable seeds, but the germination of seeds from red drupes was significantly greater than that of seeds from brown ones. This mechanism might facilitate the prolongation of seed germination and its spread along a larger period of time, thus assuring the successful germination and establishment of seedlings at least for a certain proportion of its offspring.

Based on our results, we think that further comprehensive experiments, including a detailed observation of all ontogenetic stages of fruit development and morphoanatomical analyses of the mesocarp, would help decipher whether the observed fruit morphotypes represent real fruit polymorphism or simply various stages of the ripening process. Ultimately, however, it is necessary to emphasize that, irrespective of which of the discussed hypotheses about the origin of fruit polymorphism is correct, fruits of both morphotypes are dispersed and are at least partially viable and thus play an essential role in the sexual reproduction of the species. Knowledge about their viability and germination ability is therefore crucial 
for the long-term survival of the species and future conservation activities. In consequence, because the seeds of small-fruit morphotypes get dispersed and have at least some level of viability, they should not be excluded from conservation actions such as seed collecting, storage or re-introduction programmes.

\section{Seed germination in Daphne arbuscula}

and $D$. cneorum: the cold treatment breaks

down physiological dormancy most effectively

The overall germination ability of the endemic $D$. arbuscula was generally low, irrespective of the temperature regime or the use of GA3. The greatest seed germination percentage $(63 \%)$ was achieved only after 13 weeks of warm stratification at $15^{\circ} \mathrm{C}$, followed by 28 weeks of cold stratification at $0^{\circ} \mathrm{C}$, followed by incubation at $15^{\circ} \mathrm{C}$, indicating the presence of deep physiological dormancy. In our study, even if a control test at $15^{\circ} \mathrm{C}$ without cold stratification was not performed, in the initial step of this test, 13 weeks of warm stratification at $15^{\circ} \mathrm{C}$, only $3 \%$ of the seeds germinated. This confirms that the seeds of $D$. arbuscula are physiologically dormant and require stratification to germinate. Indeed, this finding is also in good accordance with previous in situ experiments performed in an alpine garden or directly in natural sites of D. arbuscula, which revealed meagre (3-10\%) or no germination of the seeds used, respectively (Erdelská and Turis 1995, 1996).

Seeds of the genus Daphne are known to possess PD and to be challenging to germinate (Baskin and Baskin 2014; Zhang and Smagula 2000). PD is often overcome in the laboratory by a period of warm and/or cold stratification, or by the addition of chemical stimulants such as gibberellic acid (Baskin and Baskin 2014; Davies et al. 2015b; Kildisheva et al. 2020). Cold stratification was shown to be efficient at increasing germination in D. mezereum up to $82 \%$ (Zhang and Smagula 2000) or even up to $86.5 \%$ in the Chinese endemic $D$. giraldii Nitsche (Fang et al. 2016). The germination tests with various Daphne species performed in vivo revealed a distinctly low ability of seeds to germinate. Šedivá and Žlebčík (2010) analysed the seed germination of $D$. cneorum during a nine-year study in which the annual seed germination oscillated between 18 and 63\%. Germination experiments on other species, conducted in a greenhouse, revealed $33 \%$ germination in D. gnidioides Jaub. \& Spach but, unexpectedly, no germination at all in the cases of D. oleoides Schreb. and D. sericea Vahl (Ari et al.
2014), indicating strong PD in those species. Likewise, various members of closely related genera of the family Thymelaeaceae were also found to have significantly low seed germination ability. Seed germination of Thymelaea velutina, T. hirsuta (L.) Endl. and Pimelea arenaria A. Cunn. in in situ experiments were meagre, reaching in most cases only low percentages (Minuto et al. 2004; Dawson et al. 2005; de La Bandera and Travaset 2006).

The germination ability of seeds belonging to the bigfruit morphotype of $D$. arbuscula differed between the constant vs alternating temperature regimes, with a strong preference for the former. Indeed, seed viability estimated at the time of the cut test after the seeds were exposed to alternating temperatures was significantly lower than when seeds were exposed to constant temperatures, showing a negative impact of either high temperature such as $25^{\circ} \mathrm{C}$ or diurnal differences at a temperature of $20^{\circ} \mathrm{C}$. Our data are not exhaustive enough to clarify whether the low success of the tested alternating temperature was caused by a negative impact of the higher temperature of $25^{\circ} \mathrm{C}$ or by an excessive daily difference of $20^{\circ} \mathrm{C}$. Such temperatures might occur at the collecting site (Šiance) during the vegetation period, but the microclimate of the precise areas where the seeds lay between seed dispersal and germination might differ notably. It is known that soil temperatures do not reach the same temperature extremes registered in the air, therefore having a narrower amplitude between day and night and between seasons. According to Fernández-Pascual et al. (2015), who studied soil temperatures at three sites in Slovakia, during the day the soil temperature is not always significantly lower than the air temperature whereas during the night soil temperatures remain between 4 and $8^{\circ} \mathrm{C}$ higher than the air temperatures, especially when air temperatures drop below $0^{\circ} \mathrm{C}$. The seeds of $D$. arbuscula are dispersed to niches surrounding mother plants that are mostly formed by limestone crevices or cushions and tussocks of saxicolous vegetation. Such specific microhabitats might also buffer temperature conditions, but it is not clear whether this would be comparable to the 'normal' soil studied by FernándezPascual et al. (2015). Nevertheless, taken these facts into account, we might suspect that, in this case, the factor which affected seed germination and viability the most are greatly alternating temperatures, rather than maximum diurnal temperatures.

Between the tests with constant temperatures $\left(15^{\circ} \mathrm{C}\right)$, the use of $0^{\circ} \mathrm{C}$ for cold stratification led to greater germination than the use of $5^{\circ} \mathrm{C}$. This difference in 
germination success was, however, not significant statistically. In the majority of germination tests carried out in the laboratory, cold stratification using the temperature of $5^{\circ} \mathrm{C}$ is applied (Baskin and Baskin 2014; Ellis et al. 1985). In common practice, temperatures below $10^{\circ} \mathrm{C}$, similar to the climate of origin (Kildisheva et al. 2020), are used in germination experiments of this type. Both $0^{\circ} \mathrm{C}$ and $5^{\circ} \mathrm{C}$ are likely to be the actual soil temperatures at the collection site. In fact, despite the climate data showing minimum winter temperatures far below $0^{\circ} \mathrm{C}$, it is unlikely that soil temperatures reach such extreme lows (Fernández-Pascual et al. 2015). Zhang and Smagula (2000) reported the use of $4.44^{\circ} \mathrm{C}$ for $D$. mezereum, while $0^{\circ} \mathrm{C}$ is suggested for D. papyracea Wall. ex Steud. (Baskin and Baskin 2014). An important practical consequence of our experiments is the choice of the most relevant cold stratification temperature. Specifically, we showed that after the 24 weeks cold stratification, seeds germinated well if the temperature of $5^{\circ} \mathrm{C}$ was used, but no germination occurred in cases where $0^{\circ} \mathrm{C}$ was used.

With this experiment it is not possible to verify the need for warm stratification prior to cold stratification. However, the high percentage of mouldy/dead seeds found at the time of the final cut test in the long germination tests (57 to $63 \%$ viability), compared with the short germination tests using constant temperatures (78 to $91 \%$ viability), indicates that the conditions in the long test had led to the death of many seeds. We suspect that the longer stratification could be responsible for the ageing of the seeds, similarly to what Zhang and Smagula (2000) found for $D$. mezereum, for which 1 month of cold stratification was more successful than longer periods.

Interestingly, seeds of the two species studied differed in their response to GA3 treatment and its influence on dormancy. Results in D. arbuscula were in line with standard germination tests; that is, the germination success of the big-fruit morphotype after GA3 treatment was greater than of the small-fruit morphotype. On the other hand, the germination level of D. arbuscula seeds was not significantly increased after GA3 treatment, as previously indicated by Filipovič (2011). Completely opposite results were obtained in $D$. cneorum, where the small-fruit morphotype seeds germinated significantly better than those of big-fruit morphotype after exposure to GA3.

One plausible explanation for this unexpected finding could be that physiological dormancy increased during the seed ripening process, which is a common phenomenon in seed development (Baskin and Baskin 2014). A decrease in germination in correlation with the level of maturation was evidenced in $D$. mezereum by Zhang and Smagula (2000). Thus, it is tempting to speculate about potential advantages of the strategy of $D$. cneorum and D. mezereum to leave parts of the fruit not fully ripe at dispersal in order to differentiate even more the levels of dormancy of their offspring. In that way, germination would be spread from the immediate summer after dispersal to up to two or more following springs, consequently minimizing the likelihood of the death of all seedlings and helping establish at least a proportion of them. On the other hand, the absence of this mechanism in D. arbuscula could be related to its limited area of distribution and its rarity. It is to be noted that the difference in the level of dormancy between $D$. arbuscula and D. cneorum, shown by the germination tests with the use of GA3, was not due to the smallfruit morphotype, but it was entirely attributed to the big-fruit morphotype, which in D. arbuscula showed a significantly lower level of dormancy.

Practical implications for seed conservation and re-introduction

None of the germination tests achieved the germination percentage of $85 \%$ required by international seed banking standards (FAO 2013) and further investigation is needed. In particular, multiple cycles of exposure to cold-warm temperatures should be tested to increase germination percentages, as suggested by Zhang and Smagula (2000) for D. mezereum and by Alonso and Herrera (2001) for D. laureola L. In fact, spreading the seed germination across several consecutive years is a known survival strategy for plant species occurring in areas where winters are extremely cold and chances of losing their offspring in the first year are high (Kildisheva et al. 2020).

We recommend including both fruit morphotypes when collecting seed of Daphne for ex situ conservation and re-introduction initiatives. This enables to maintain the original genetic diversity of the species and secure their future survival. Knowing about the variability in fruit morphology and associated viability of the seeds of the small-fruit morphotype informs seed bank managers and seed conservation practitioners and determines best practice for seed collection and subsequent seed processing of $D$. arbuscula and D. cneorum. 
Concerns arise in relation to seed banking potentially immature seeds, as these could not have developed full desiccation tolerance or full longevity (Way and Gold 2014). Reassuringly, we found seeds of small green/ brown fruits to be tolerant of desiccation, as the seeds used here were dried at $15 \%$ equilibrium relative humidity at $15^{\circ} \mathrm{C}$ and kept at these conditions for several months prior to testing. However, as not all seeds were viable after storage, testing the viability of freshly collected seeds would be needed to exclude potential negative effects of drying on part of the seeds. Furthermore, the effect of freezing at $-20^{\circ} \mathrm{C}$ following international standards for conventional seed banking (Breman and Way 2018) was not tested, and further investigation is needed to assess the orthodox behaviour of these seeds and their longevity ex situ.

When performing tetrazolium tests on seeds of Daphne, we recommend including seeds coloured mostly in red but with slight patches of pink as viable.

Supplementary information The online version contains supplementary material available at https://doi.org/10.1007/s12224021-09389-5.

\begin{abstract}
Acknowledgements We would like to acknowledge Dr Efisio Mattana for his precious advice during the analysis and the writing of this paper. We are much indebted to Blažena Sedláková, Drahoš Blanár and Ivan Bryndza for their kind assistance during seed collecting field trips. Laboratory work for this study was funded by the Garfield Weston Foundation, as part of the Global Tree Seed Bank Project managed by the Royal Botanic Gardens, Kew. Field work for this study took place in the context of the project 'Conserving the endemic flora of the Carpathian Region', managed by the Institute of Botany of the Slovak Academy of Sciences.
\end{abstract}

\section{Declarations}

Conflict of interest The authors declare no conflict of interest.

Open Access This article is licensed under a Creative Commons Attribution 4.0 International License, which permits use, sharing, adaptation, distribution and reproduction in any medium or format, as long as you give appropriate credit to the original author(s) and the source, provide a link to the Creative Commons licence, and indicate if changes were made. The images or other third party material in this article are included in the article's Creative Commons licence, unless indicated otherwise in a credit line to the material. If material is not included in the article's Creative Commons licence and your intended use is not permitted by statutory regulation or exceeds the permitted use, you will need to obtain permission directly from the copyright holder. To view a copy of this licence, visit http://creativecommons.org/licenses/by/4.0/.

\section{References}

Alonso C, Herrera CM (2001) Neither vegetative nor reproductive advantages account for high frequency of male-steriles in southern Spanish gynodioecious Daphne laureola (Thymelaeaceae). Amer J Bot 88:1016-1024

Ari E, Gürbüz E, Tuğrul AY (2014) Seed germinations of 20 wild species growing in Antalya (Turkey) with outdoor ornamental plant potencial. Fifth International Scientific Agricultural Symposium 'Agrosym 2014', pp 439-445

Baskin JM, Baskin CC (2014) Seeds: ecology, biogeography, and evolution of dormancy and germination. Academic Press

Breman E, Way M (2018) Safe for the future: seed conservation standards developed for the Millennium Seed Bank Partnership. Proceedings of the EuroGard VII Congress (July 6-10, 2015). The European Botanic Gardens Consortium, Paris, pp 267-274

R Core Team (2020) R: a language and environment for statistical computing. R Foundation for Statistical Computing, Vienna, Austria. Available at https://www.R-project.org

Davies R, Di Sacco A, Newton R (2015a) Germination testing: procedure and evaluation. Technical Information Sheet_13a. Roy. Bot. Gardens Kew. Available at http://brahmsonline. kew.org/Content/Projects/msbp/resources/Training/13aGermination-testing-procedures.pdf

Davies R, Di Sacco A, Newton R (2015b) Germination testing: environmental factors and dormancy-breaking treatments. Technical Information Sheet_13a. Roy. Bot. Gardens Kew. Available at http://brahmsonline.kew. org/Content/Projects/msbp/resources/Training/13bGermination-testing-dormancy.pdf

Davies RM, Newton RJ, Hay FR, Probert RJ (2016) 150-seed comparative longevity protocol - a reduced seed number screening method for identifying short-lived seed conservation collections. Seed Sci Technol 44:569-584

Dawson PAC, Rapson GL, Robertson A, Fordham RA (2005) Limitations on recruitment of the rare sand daphne Pimelea arenaria (Thymelaeaceae), lower North Island, New Zealand. New Zealand J Bot 43:619-630

de la Bandera MC, Travaset A (2006) Reproductive ecology of Thymelaea velutina (Thymelaeaceae) - factors contributing to the maintenance of heterocarpy. Pl Syst Evol 256:97-112

Ellis RH, Hong TD, Roberts EH (1985) Handbook of seed technology for genebanks, Volume I: Principles and Methodology. International Board for Plant Genetic Resources, Rome. Available at https:/www.bioversityinternational.org/elibrary/publications/detail/handbookof-seed-technology-forgenebanks-1

Erdelská O (1998) Vývin a degenerácia vajíčok lykovca kríčkovitého (Daphne arbuscula Čelak.) [Development and degeneration of ovules of Daphne arbuscula]. In Benčat'ová B, Hrivnák R (eds), Rastliny a človek. Technická univerzita, Zvolen, pp 37-40 
Erdelská O (1999) Successive tissue degeneration in unfertilized ovules of Daphne arbuscula. Acta Biol Crac 41:163-167

Erdelská O, Petušík J, Pelikán V (1989) Vývin semien lykovca muránskeho [Development of the seeds of Daphne arbuscula]. Biologia, Bratislava 44:13-19

Erdelská O, Turis P (1995) Biology of Daphne arbuscula Čelak. (Thymelaeaceae). Biologia, Bratislava 50:333-348

Erdelská O, Turis P (1996) Lykovec muránsky (Daphne arbuscula Čelak.). SAŽP - Správa CHKO Muránska planina, Rožňava

Fang Y, Zhang E, Qinli W, Zhuhong M (2016) Germination and dormancy-breaking of Daphne giraldii Nitsche (Thymelaeaceae) seeds from northwestern China. Revista Chapingo, Ser Ci Forest Amb 22:99-113

FAO (2013) Genebank standards for plant genetic resources for food and agriculture. Rome. Available at http://www.fao. org/docrep/019/i3704e/i3704e.pdf

Fernández-Pascual E, Jiménez-Alfaro B, Hájek M, Díaz TE, Pritchard HW (2015) Soil thermal buffer and regeneration niche may favour calcareous fen resilience to climate change. Folia Geobot 50:293-301

Filipovič P (2011) Využitie reprodukčných metód pre zachovanie vybraných zložiek genofondu lykovca muránskeho (Daphne arbuscula Celak.). [Use of reproductive methods for the conservation of selected parts of the gene pool of Daphne arbuscula Čelak.] Doctoral thesis, Slovak Agriculture University in Nitra

Gajdošová Z (2018) Reprodukčné mechanizmy západokarpatského stenoendemického druhu Daphne arbuscula Čelak. (Thymeleaceae) [Reproduction of the West Carpathian stenoendemic species Daphne arbuscula Čelak. (Thymelaeaceae)]. Bachelor thesis, Matej Bel University in Banská Bystrica

Halda J (2001) The genus Daphne. SEN Dobré, Hronov

Imbert E (2002) Ecological consequences and ontogeny of seed heteromorphism. Perspect Pl Ecol Evol Syst 5:13-36

Kildisheva OA, Dixon KW, Silveira FAO, Chapman T, Di Sacco A, Mondoni A, TurnerSR, Cross AT (2020) Dormancy and germination: making every seed count in restoration. Restorat Ecol 28:S256-S265

Kochjarová J, Turis P, Feráková V (1999) Daphne arbuscula Čelak. In Čeřovský J, Feráková V, Holub J et al. (eds) Červená kniha ohrozených a vzácnych druhov rastlin a živočichov SR a ČR 5 Vyššie rastliny [Red book of endangered and rare species of plants and animals of the Slovak Republic and the Czech Republic 5 - Higher plants]. Príroda, Bratislava, p 456

Krippel E, Goliašová K. (1988) Thymelaeaceae Juss. Vrabcovníkovité. In Bertová L (eds) Flóra Slovenska IV/4: Angiospermophytia. Dicotyledonopsida. FabalesConvolvulales, Veda, Bratislava, pp. 508-519

Lozano-Isla F, Benites-Alfaro OE, Pompelli MF (2019) GerminaR: an $\mathrm{R}$ package for germination analysis with the interactive web application 'GerminaQuant for R'. Ecol Res 34:339-346

Marhold K, Mártonfi P, Mered’a P jun, Mráz P (eds) (2007) Chromosome number survey of the ferns and flowering plants of Slovakia. Veda, Bratislava

Mathew B (1989) Daphne kiusiana (Thymelaeaceae). Kew Mag 6: $112-115$

Minuto L, Casazza G, Profumo P (2004) Population decrease of Thymelaea hirsuta (L.) Endl. in Liguria: conservation problems for the North Tyrrhenian sea. Pl Biosyst 138:11-19
Mohamed-Yasseen Y, Barringer SA, Splittstoesser WA, Costanza S (1994) The role of seed coats in seed viability. Bot Rev 60: 426-439

Murín A (1990) Karyology of an endemic species Daphne arbuscula Čelak. Botanica 37:35-40

Newton RJ, Hay FR, Ellis RH (2013) Seed development and maturation in early spring-flowering Galanthus nivalis and Narcissus pseudonarcissus continues post-shedding with little evidence of maturation in planta. Ann Bot (Oxford) 111:945-955

Pedrini S, Gibson-Roy P, Trivedi C, Gálvez-Ramírez C, Hardwick K, Shaw N, Frischie S, Laverack G, Dixon K (2020) Collection and production of native seeds for ecological restoration. Restorat Ecol 28:228-238

Pedrol J (2011) Daphne arbuscula. Euro+Med Plantbase - the information resource for Euro-Mediterranean plant diversity. Available at http://ww2.bgbm.org/EuroPlusMed/PTaxonDetail. asp?NameCache=Daphne $\%$ 20arbuscula\&PTRefFk=7400000

Ranal MA, de Santana DG, Ferreira WR, Mendes-Rodrigues C (2009) Calculating germination measurements and organizing spreadsheets. Revista Brasil Bot 32:849-855

RStudio Team (2019) RStudio: integrated development for $R$. RStudio, Inc., Boston. Available at http://www.rstudio.com

Šedivá J, Žlebčík J (2010) Vegetative and generative propagation of the endangered species Daphne cneorum L. Acta Prìhon 96:15-18

Tebar FJ, Llorens L (1993) Heterocarpy in Thymelaea velutina Endl.: a case of phenotypic adaptation to Mediterranean selective pressures. Bot J Linn Soc 111:295-300

Turis P (1994) Abnormity osí a kvetov lykovca muránskeho [Abnormities of the axes and flowers of Daphne arbuscula]. Živa 1994:165-166

Turis P, Smetana V (1997) Príspevok k poznaniu interakcií medzi hmyzom a lykovcom muránskym [Note on the knowledge of the interactions between insects and Daphne arbuscula]. In Uhrin M (ed) Výskum a ochrana prírody Muránskej planiny, Revúca, pp 71-74

Tutin TG (1968) Daphne In Tutin TG, Heywood VH, Burges NA, Valentine DH, Walters SM, Webb DA (eds) Flora Europaea Vol. 2, Rosaceae to Umbelliferae. Cambridge University Press, Cambridge, p 454

Way M, Gold K (2014) Technical information sheet_02. 'Assessing a population for seed collection' Millennium Seed Bank Partnership, Kew. Available at http://brahmsonline.kew. org/Content/Projects/msbp/resources/Training/02-581 Assessingpopulation.pdf

White R (2006) Daphnes: a practical guide for gardeners. USA Timber Press, Inc The Haseltine Building

Yinzheng W, Gilbert MG, Mathew BF, Brickell CH (2007) Daphne L. Wu ZY, Raven PH, Hong DY (eds) Flora of China. Vol. 13 (Clusiaceae through Araliaceae). Science Press, Beijing, and Missouri Botanical Garden Press, St. Louis, pp 230-245

Zhang D, Smagula J (2000) Seed germination of Daphne mezereum: fruit stages, cold treatment, and more. Comb Proc Int Pl Propag Soc 50:442-444

Publisher's note Springer Nature remains neutral with regard to jurisdictional claims in published maps and institutional affiliations. 